BARNABY RICH

A Short Biography 
Dag Sas quickle Defermineo, ano likelwife bonoureo boith the pzefence of all thefe pzinees, beere began againe feathing amo banqueting afreth. Itill enterlaroing tbeir oiches twith fuch pleafures as couto nott aptlp be pzepareo foz the pzefent:baring thus for a learon, fpent the time afmuct to tbeir owne contentment as might bee, ano after tbey bao combine a perpetuall league of frenothip betweene tbemCelues, thee departeo, Myletto ano bis queene to Hungaria, Doreftus ano Leonida to Epirus, Brufanus ano Moderna to Dalmatia, Lobich was ber inbiritaunce, Antipholus ans Valeria, contimus in Illeria, ano thep feuerallg raigneo, in perfer loue ano amity betweene tbemfelues, gouerning their people witb fucb equity ano iutrice, as tbey neitber wanteo loue to tbeir fabiedes, noz their fubiedes ouctp ano obebience totbem : all parties tbus pleafso, ano euerp one remaining in mot bappr contentment, 3 bolo it be

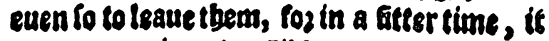
is not portiblesoens.

\section{FINIS.}

Barnaby Rich.

Malui me divitem effe guam rocari.

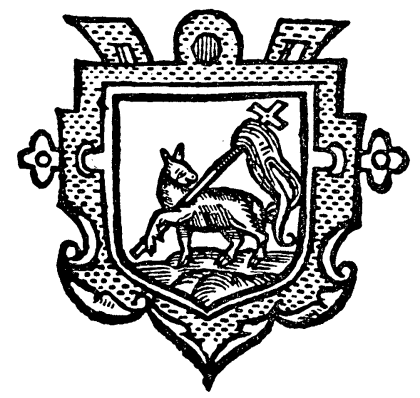

Reproduction of the last page of Rich's The Adventures of Brusanus (1592), containing Rich's motto and a coat of arms, presumably bis, in the colophon 


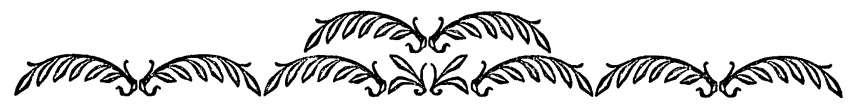

\title{
BARNABY RICH
}

\author{
A Short Biography
}

By Thomas M. Cranfill

and Dorothy Hart Bruce

म000

AUSTIN : I953

UNIVERSITY OF TEXAS PRESS 


\section{UNIVERSITY OF TEXAS PRESS}

Austin 12

\section{THOMAS NELSON AND SONS LTD}

Parkside Works Edinburgh 9

3 Henrietta Street London WC2

312 Flinders Street Melbourne C1

5 Parker's Buildings Burg Street Cape Town

Thomas Nelson and Sons (Canada) Ltd

91-93 Wellington Street West Toronto 1

Société Française d'Editions Nelson

25 rue Henri Barbusse Paris $V^{\mathbf{e}}$

Library of Congress Catalogue Card No. 53-6002

Copyright 1953 by the University of Texas Press

Printed in Austin, Texas, U.S.A.,

by the Printing Division of the University of Texas 